\title{
Relação das dissertações defendidas no Programa de Pós-Graduação Stricto Sensu em Educação da Universidade São Francisco no período de julho a dezembro de 2012
}

GALLEGO, Eduardo Manuel Bartalini. Investigando as práticas de ensinar e aprender matemática nos anos iniciais do ensino Fundamental em um grupo do PIBID. 2012. Dissertação (Mestrado em Educação), Programa de Pós-Graduação Stricto Sensu em Educação. Universidade São Francisco, Itatiba/SP. Orientadora: Regina Célia Grando.

A presente pesquisa foi desenvolvida em um grupo constituído por estudantes do curso de Pedagogia de uma universidade em uma cidade do interior do estado de São Paulo e professoras que atuam nos anos iniciais do ensino fundamental em uma escola municipal dessa mesma cidade e que fazem parte do Programa de Bolsas de Iniciação à Docência - PIBID. A pesquisa foi desenvolvida em uma abordagem qualitativa, a partir da constituição de um grupo que, em alguns momentos, assumiu dimensões colaborativas. Buscamos responder à seguinte questão: "Quais são as contribuições de uma parceria entre universidade e escola para as práticas de ensino de matemática nos anos iniciais?". Nosso objetivo é (1) "conhecer o movimento de resistências e transformações nas culturas escolares de uma escola, decorrentes do trabalho compartilhado no grupo"; e (2) "identificar as reflexões produzidas pelas professoras sobre os processos de aprender a ensinar matemática quando compartilham suas práticas no grupo". Para tanto, houve o acompanhamento do grupo em encontros quinzenais nas oficinas de educação matemática, que foram audiogravadas e transcritas. Também foram realizadas entrevistas individuais com as professoras que atuam nos anos iniciais e com os estudantes de Pedagogia, futuros professores. Essas entrevistas foram textualizadas para que fossem apresentadas as "vozes" dos atores envolvidos na pesquisa. Além das transcrições das audiogravações e das entrevistas, foram utilizados como fonte de dados os relatórios anuais do projeto PIBID dos participantes do grupo As análises e as sistematizações dos resultados foram discutidas em dois capítulos, um dedicado à discussão da cultura escolar e cultura de aula de matemática, destacando as tensões e desafios enfrentados pelo grupo, e outro com as reflexões das professoras, estudantes e as produzidas na interação do grupo. Como resultados identificamos os processos reflexivos propiciados pelo grupo de discussão, bem como a carência dos professores de um bom conhecimento epistemológico dos conceitos matemáticos. Também se evidenciou que o PIBID proporcionou uma modificação nas metodologias utilizadas nas salas de aula em que o grupo atuou, embora não se evidencie mudança de concepção enquanto à matemática e seu ensino nos anos iniciais do ensino fundamental. Em relação às políticas públicas em formação de professores, o PIBID se destaca como um espaço que contribui, em potencial, para a inserção do futuro professor nas práticas de ensinar e aprender, nesse caso, a matemática, bem como possibilita reflexões às professoras da escola sobre suas práticas pedagógicas. Com base nesse e em outros resultados, foram produzidas nossas considerações finais, destacando a possibilidade do grupo como um espaço reflexivo e as apropriações dos conceitos matemáticos pelas professoras.

Palavras-chave: Formação de professores, Estratégias formativas, PIBID, Educação Matemática. 